\title{
Evaluation of Organic Manures, Fermented Organics and PGPR on Plant Growth and Soil Properties under Capsicum (Capsicum annuum L.)
}

\author{
Perminder Singh Brar*, Rajesh Kaushal, Gitika Bhardwaj
}

Department of Soil Science and Water Management, Dr Y S Parmar University of Horticulture and Forestry Nauni, Solan, Himachal Pradesh 173230, India

*Corresponding author

\section{A B S T R A C T}

\begin{tabular}{l} 
Ke y w o r d s \\
Capsicum, Poultry \\
Manure, \\
Vermicompost, \\
Jeevamrut, \\
Panchagavya, \\
Amritpani, PGPR \\
\hline Article Info \\
$\begin{array}{l}\text { Accepted: } \\
\text { 18 May 2020 } \\
\text { Available Online: } \\
\text { 10 June } 2020\end{array}$ \\
\hline
\end{tabular}

\section{Introduction}

Bell peppers are enriched with vitamin A and C. Capsicum annuum and C. frutescens are $3^{\text {rd }}$ among the cultivated vegetables which are also used as spice (Nwachukwu et al., 2007). The fruits are ascorbic acid rich and recognized by capsaicin and capsanthin content. Capsicum is cultivated in an area of about 32,150 ha and annual production of 1.82 lakh MT in India whereas in Himachal Pradesh, the capsicum is cultivated over an of soil.
The present investigation was carried out to find out combined effect of bulky manures, liquid organic inputs and bio fertilizers on plant growth, plant nutrient content and soil properties under capsicum (Capsicum annuum L.). The experiment was laid out in Randomized Block Design with 7 different treatments. The maximum plant height $(58.5 \mathrm{~cm})$, plant biomass $(66.40$ $\mathrm{g}$ plant $\left.^{-1}\right)$, number of fruits (15.24 plant $\left.^{-1}\right)$ were recorded significantly in treatment $\mathrm{T}_{2}$ comprising 90\% RDN along with PGPR and fermented organics. The maximum fruit yield (31.15 t ha $\mathrm{ta}^{-1}$ and $\left.1.051 \mathrm{~kg} \mathrm{plant}^{-1}\right)$, NPK content in shoot $(5.29,0.64$ and 6.27\%), root (4.23, 0.66 and $3.54 \%)$, fruit $(4.63,0.61$ and $4.23 \%)$ and the highest uptake of NPK $(14.25,1.87$ and $13.81 \mathrm{~kg} \mathrm{ha}^{-1}$ ) and among soil properties, significant higher value of available macronutrient (445.33, 77.80, and $296.69 \mathrm{~kg} \mathrm{ha}^{-1}$ ), available micronutrient $\mathrm{Zn}, \mathrm{Cu}, \mathrm{Fe}$, and $\mathrm{Mn}(2.37,2.33$, 6.73 and $2.62 \mathrm{ppm}$ respectively) and organic carbon $\left(1.33 \%\right.$ ) were observed in treatment $\mathrm{T}_{2}$. Similarly, among various microbial properties viz, microbial count, microbial biomass and soil enzymes such as Dehydrogenase, Phosphatase and Urease activities were also recorded significantly maximum in treatment $\mathrm{T}_{2}$ as compared to $\mathrm{T}_{1}$. This investigation concluded that the application of treatment $\mathrm{T}_{2}(90 \% \mathrm{RDN}$ by Vermicompost and Poultry Manure along with fermented organics i.e. Panchagavya, Jeevamrut, Amritpani and liquid bio-fertilizer) significantly enhanced plant growth parameters, soil parameters and microbiological properties

area about 2070 ha, annual production is 34.13 thousand MT (Anonymous, 2016). The states which are leading in production of capsicum in India are Himachal Pradesh, Karnataka, Tamil Nadu, Maharashtra, Andhra Pradesh, Uttaranchal, Madhya Pradesh, West Bengal, Rajasthan, Punjab, and Orissa.

Organic farming is promoted due to its efficient approach which bind crop yield to ecology and associate with common objective of healthy environment for all the living 
beings. Organic manure increases the yield and long-term usage will give maximum output (Brar et al., 2019). The ill effects of chemical inputs both on yield, soil and human health has generated, interest among the scientific community for the use of nonpolluting, environment friendly organic amendments and it became imperative to use cheaper source of nutrients like organic manures to improve crop productivity and soil health (Follett et al., 1981).

A significant higher plant height, canopy and yield of bell pepper recorded by the application of organic fertilizers compared to the use of synthetic fertilizers (Legaspi et al., 2007). To achieve sustainable crop productivity without degrading soil health significant role is played by bulky manures (like Farm Yard Manure, Vermicompost and Poultry Manure), concentrated manures (edible and non-edible cakes) and liquid organic formulations (Panchagavya, Jeevamrut and Amritpani). These sources of nutrients along with bio-fertilizers/PGPR are becoming popular among farmers who are converting themselves from chemical farming to Organic Farming (OF).

\section{Materials and Methods}

The experimental field is situated at the research farm of the Department of Soil Science and Water Management, Dr. Y S Parmar University of Horticulture and Forestry, Nauni, Solan (HP) and field experiments were conducted during 2017. The climate of experimental area falls in subtemperate, sub-humid agro-climatic zone-II of Himachal Pradesh. In this area, the hottest months are May and June whereas coldest months are December-January. The maximum rainfall received during monsoon period (midJune to mid-September) and the average annual rainfall is about $1115 \mathrm{~mm}$. The experimental area is having soil fall in order
Inceptisol, sub group Eutrochrept according to Soil Taxonomy of USDA. The experiment was laid out in Randomized Block Design with seven treatments and three replications during 2017. The seven treatment combinations viz.

$\mathrm{T}_{1}: 100 \%$ Recommended Doses of Nutrients only through Poultry manure and Vermicompost. $\quad \mathrm{T}_{2}$ : $90 \% \quad \mathrm{RDN}$ through Poultry manure and Vermicompost with application of PGPR and fermented organic formulation (Panchagavya, Jeevamrut and Amritpani).

$\mathrm{T}_{3}: 80 \%$ RDN through Poultry manure and Vermicompost with application of PGPR and fermented organic formulation (Panchagavya, Jeevamrut and Amritpani).

$\mathrm{T}_{4}: 70 \%$ RDN through Poultry manure and Vermicompost with application of PGPR and fermented organic formulation (Panchagavya, Jeevamrut and Amritpani).

$\mathrm{T}_{5}: 60 \%$ RDN through Poultry manure and Vermicompost with application of PGPR and fermented organic formulation (Panchagavya, Jeevamrut and Amritpani).

$\mathrm{T}_{6}: 50 \%$ RDN through Poultry manure and Vermicompost with application of PGPR and fermented organic formulation (Panchagavya, Jeevamrut and Amritpani).

$\mathrm{T}_{7}: 40 \%$ RDN through Poultry manure and Vermicompost with application of PGPR and fermented organic formulation (Panchagavya, Jeevamrut and Amritpani).

Vermicompost, poultry manure (both are applied in 50:50 of Nitrogen equivalence), PGPR is applied as seedling dip for 2 hours at the time of transplanting and organic liquid manures like Panchagavya, Jeevamrut and Amritpani were applied @ 5\% and 50 ml per 
plant at 15 days interval repeatedly, acts as source of nutrients and applied in according to treatments.

\section{Plant analysis}

The plant height, root length plant biomass and was measured at the end of crop season. Plant samples (fruit, shoot, and root) collected were washed, air dried in shade, subsequently in an oven at $65 \pm 5^{\circ} \mathrm{C}$ till constant weight, grounded in an electric grinder and stored in paper bags for chemical analysis. Total nitrogen was determined by micro-kjeldahl method. Phosphorous in the extract was determined by vanado-molybdo yellow colour method (Jackson, 1973). Potassium was determined by flame photometric method. The $\mathrm{Cu}, \mathrm{Fe}, \mathrm{Mn}, \mathrm{Zn}$ were determined in the extract using Atomic Absorption Spectrophotometer.

\section{Soil analysis}

Composite soil samples from $0-15 \mathrm{~cm}$ soil depth were collected before start of experiment. After crop harvesting soil samples from each plot were collected to ascertain the effect of different organic inputs on $\mathrm{pH}$ and $\mathrm{EC}$, which were determined in soil: water suspension (1:2) according to Jackson (1973). Organic carbon was determined by Rapid titration method (Walkley and Black, 1934). Available $\mathrm{N}$ in soil was determined by Alkaline potassium permanganate method (Subbiah and Asija, 1956), available P by stannous chloride reduced ammonium molybdate method using Olsen's extractant (Olsen et al., 1954) and available potassium was extracted by Ammonium acetate method (Merwin and Peech, 1951) and estimated on flame photometer and DTPA extractable Zn, $\mathrm{Fe}, \mathrm{Mn}, \mathrm{Cu}$ were estimated on Atomic Absorption Spectrophotometer (Lindsay and Norvell, 1978). Among microbiological properties, total microbial count which was determined by standard spread plate technique (Subbarao, 1999). The estimation of Microbial biomass-C was carried out by soil fumigation extraction method (Vance et al., 1987). Soil enzymes i.e. Dehydrogenase was estimated by method given by Casida et al., (1964), Phosphatase enzyme estimation by method given by Tabatabai and Bremmer (1969) and Urease enzyme was determined by method given by Hoffman (1965).

\section{Results and Discussion}

\section{Plant growth parameters}

Plant growth parameters like plant height, root length, plant biomass, number of fruits per plant, fruit yield (per hectare and per plant) were significantly affected by different organic amendments like Poultry manure, Vermicompost and FYM, Panchagavya, Jeevamrut, Amritpani (given in Table 1). Plant with $90 \%$ Recommended dose of nutrients (RDN) + PGPR inoculation + fermented organics i.e. $\mathrm{T}_{2}$ treatment exhibited maximum increase in plant height $(58.5 \mathrm{~cm})$ of capsicum, higher plant biomass $(66.40 \mathrm{~g}$ plant $^{-1}$ ), highest (15.24) number of fruits per plant were significantly recorded. Also, maximum fruit yield $\left(31.15 \mathrm{t} \mathrm{ha}^{-1}\right.$ and 1.051 $\mathrm{kg}$ fruit yield per plant) was recorded with treatment $\mathrm{T}_{2}$. Also, studies conducted by Brar et al., (2020) concluded that the bulky manures (vermicompost and poultry manure) in combination with PGPR and folk liquid manures have significant impact to increase the plant height and biomass in capsicum crop. Increase in rice yield with integrated use of different combinations of FYM, Sesbania and chemical fertilizers was also reported by Mehdi et al., (2011). Significantly higher number of fruits by the application of farm yard manure and vermicompost in Watermelon was recorded by Aniekwe and Nwoku (2013). However maximum $(15.6 \mathrm{~cm})$ root length was recorded in $\mathrm{T}_{3}$ with $80 \%$ 
$\mathrm{RDN}+\mathrm{PGPR}+$ fermented organics and the minimum $(10.4 \mathrm{~cm})$ root length was revealed in $\mathrm{T}_{7}$ i.e. $40 \% \mathrm{RDN}+\mathrm{PGPR}+$ fermented organics. However, $\mathrm{T}_{1}(100 \% \mathrm{RDN})$ and $\mathrm{T}_{4}$ (70\% RDN + PGPR + fermented organics) was statistically at par with root length of 12.8 $\mathrm{cm}$ and $13.1 \mathrm{~cm}$, respectively. Similar results were observed by Brar et al., (2020) who found that with increasing application of bulky manures + folk liquid manures and PGPR, root length in capsicum crop increases.

\section{Plant nutrient content}

\section{Total NPK content in shoot}

Total NPK content in shoot was significantly influenced by different treatments as shown in Table 2. The effect of different treatments was significant and highest $(5.29 \%)$ total nitrogen, $(0.64 \%)$ total phosphorous content, total potassium $(6.27 \%)$ were recorded for treatment $\mathrm{T}_{2}(90 \% \mathrm{RDN}$ along with PGPR and fermented organics). Similar results were also found by Ravimycin (2016), who reported that by application of vermicompost and farm yard manure there is increase in nutrient content of coriander plants.

\section{Total NPK content in root}

An examination of the data presented in Table 2 reveals that the highest total nitrogen content $(4.23 \%),(0.66 \%)$ total phosphorous content and $(3.54 \%)$ total potassium content in root, observed under treatment $\mathrm{T}_{2}(90 \%$ $\mathrm{RDN}+\mathrm{PGPR}+$ fermented organics). Similar results were also reported by Mia et al., (2010) who observed that PGPR inoculation enhanced NPK content in roots.

\section{Total NPK content in fruit}

The data presented in Table 2 indicated that highest total NPK content in fruit i.e. $4.62 \%$,
$0.61 \%$ and $4.23 \%$ respectively was observed under treatment $\mathrm{T}_{2}(90 \% \mathrm{RDN}+\mathrm{PGPR}+$ fermented organics). These results are in line with the studies carried out by Weber et al., (2007) who found that application of compost significantly increased NPK content in plant and along with this soil properties are also affected.

\section{Total uptake}

The total uptake by plant is influenced significantly by different treatments. The highest value of total nitrogen $\left(14.25 \mathrm{~kg} \mathrm{ha}^{-1}\right)$, phosphorous (1.87 $\mathrm{kg} \mathrm{ha}^{-1}$ ) and potassium (13.81 kg ha-1) uptake was recorded in treatment $\mathrm{T}_{2}(90 \% \mathrm{RDN}+$ fermented organics + PGPR) as given in Table 2. The lowest value of total uptake of nitrogen (6.54 $\left.\mathrm{kg} \mathrm{ha}{ }^{-1}\right)$, phosphorous (0.62 $\left.\mathrm{kg} \mathrm{ha}^{-1}\right)$ and potassium $\left(7.16 \mathrm{~kg} \mathrm{ha}^{-1}\right)$ was recorded in treatment $\mathrm{T}_{7}(40 \% \mathrm{RDN}+\mathrm{PGPR}+$ fermented organics). Similar findings were reported by Turan et al., (2010), they found that by the application of PGPR, there is significant increase in macro and micronutrient nutrient uptake.

\section{Soil properties}

Among soil properties, soil $\mathrm{pH}$ and EC were non-significantly affected by different treatment combinations however the value of $\mathrm{pH}$ and EC ranged from 6.63 to 7.53 and 0.57 to $78 \mathrm{dS} \mathrm{m}^{-1}$ respectively. These results are in accordance with the results of Brar et al., (2020) who found that application of manures, Soil recipes and PGPR have no significant effect on soil $\mathrm{pH}$ and $\mathrm{EC}$ in bell pepper. The organic carbon, available Nitrogen, available Phosphorus and available Potassium and DTPA extractable micronutrient cations were significantly affected by different treatment combinations. The highest $(1.33 \%)$ organic carbon was recorded in $\mathrm{T}_{2}$ and lowest $(1.03 \%)$ was 
recorded in $\mathrm{T}_{7} \quad(40 \%$ RDN through vermicompost and poultry manure + PGPR + fermented organics). These results are in accordance with the results of Das and Singh (2014) who reported that application of farm yard manure (FYM), legume compost, cereal compost and PGPR had significantly increase organic carbon of soil.

Also significant higher (445.33 $\left.\mathrm{kg} \mathrm{ha}^{-1}\right)$ value of available nitrogen, higher (77.80 kg ha ${ }^{-1}$ ) content of available phosphorous and higher (296.69 $\mathrm{kg} \mathrm{ha}^{-1}$ ) value of available potassium was recorded under treatment $\mathrm{T}_{2}$ having $90 \%$ RDN with PGPR and also fermented organics (panchagavya, jeevamrut and amritpani). Studies carried out by Boateng et al., (2006) also demonstrated that in maize there was 53 $\%$ increase in available $\mathrm{N}$ by the application of poultry manure. Also results are in accordance with the findings of Singh and
Subba Rao (1979) who found that biofertilizers (Azospirillum brasilense with Rhizobium japonicum) increased the available phosphorus content in soil. Further Aziz et al., (2010) observed that application of farm yard manure significantly enhance the available potassium content in soil.

The maximum $\mathrm{Zn}, \mathrm{Cu}, \mathrm{Fe}, \mathrm{Mn}$ viz. 2.37 ppm, $2.33 \mathrm{ppm}, 6.73 \mathrm{ppm}, 2.62 \mathrm{ppm}$ available micronutrients cations were also recorded in $\mathrm{T}_{2}$ with $90 \% \mathrm{RDN}+\mathrm{PGPR}+$ fermented organics and minimum $(\mathrm{Zn}, \mathrm{Cu}, \mathrm{Fe}, \mathrm{Mn}$ viz. 1.19 ppm, 1.24 ppm, 4.76 ppm, 1.08 ppm) available micronutrient cations were obtained in $\mathrm{T}_{7}$ i.e. $40 \% \mathrm{RDN}+\mathrm{PGPR}+$ fermented organics. The present results are similar with the results of Jain et al., (2014) who reported that Panchagavya application had significant effect on available micronutrient in different plant seedlings.

Table.1 Evaluation of organic manures, fermented organics and PGPR on plant growth parameters under Capsicum (Capsicum annuиm L.)

\begin{tabular}{|c|c|c|c|c|c|c|}
\hline Treatments & $\begin{array}{l}\text { Plant Height } \\
\text { (cm) }\end{array}$ & $\begin{array}{l}\text { Root Length } \\
\quad(\mathrm{cm})\end{array}$ & $\begin{array}{l}\text { Plant Biomass } \\
\quad\left(\text { g plant }^{-1}\right)\end{array}$ & $\begin{array}{c}\text { No. of } \\
\text { fruits } \\
\text { per plant }\end{array}$ & $\begin{array}{c}\text { Fruit yield } \\
\text { per plant } \\
\text { (kg) }\end{array}$ & $\begin{array}{c}\text { Fruit } \\
\text { yield } \\
\left(\mathbf{t} \text { ha }^{-1}\right)\end{array}$ \\
\hline T1 & 45.7 & 13.0 & 57.95 & 13.17 & 0.737 & 21.85 \\
\hline $\mathbf{T 2}$ & 58.5 & 14.7 & 66.40 & 15.24 & 1.051 & 31.15 \\
\hline T3 & 49.7 & 15.6 & 63.73 & 13.03 & 0.847 & 25.09 \\
\hline T4 & 47.0 & 13.4 & 58.20 & 12.91 & 0.749 & 22.18 \\
\hline T5 & 43.9 & 12.2 & 54.77 & 10.78 & 0.571 & 16.93 \\
\hline T6 & 38.4 & 11.5 & 53.47 & 9.40 & 0.479 & 14.20 \\
\hline T7 & 36.9 & 10.4 & 44.67 & 10.03 & 0.391 & 11.59 \\
\hline Mean & 45.7 & 13.0 & 57.03 & 12.08 & 0.689 & 20.43 \\
\hline $\mathrm{CD}_{(0.05)}$ & 3.21 & 1.42 & 3.31 & 1.77 & 0.12 & 3.44 \\
\hline
\end{tabular}


Table.2 Evaluation of organic manures, fermented organics and PGPR on plant nutrient content under Capsicum (Capsicum annuum L.)

\begin{tabular}{|c|c|c|c|c|c|c|c|c|c|c|c|c|}
\hline \multirow{2}{*}{ Treatments } & \multicolumn{3}{|c|}{ Shoot (\%) } & \multicolumn{3}{c|}{ Root (\%) } & \multicolumn{3}{c|}{ Fruit (\%) } & \multicolumn{3}{c|}{ Uptake (kg ha $\left.{ }^{-1}\right)$} \\
\cline { 2 - 14 } & N & P & K & N & P & K & N & P & K & N & P & K \\
\hline T1 & 4.46 & 0.58 & 5.96 & 3.92 & 0.57 & 3.40 & 4.31 & 0.53 & 3.92 & 10.89 & 1.45 & 11.40 \\
\hline T2 & 5.29 & 0.64 & 6.27 & 4.23 & 0.66 & 3.54 & 4.63 & 0.61 & 4.23 & 14.25 & 1.87 & 13.81 \\
\hline T3 & 4.51 & 0.59 & 6.16 & 3.95 & 0.63 & 3.49 & 4.54 & 0.57 & 3.95 & 12.27 & 1.70 & 12.84 \\
\hline T4 & 4.46 & 0.58 & 5.96 & 3.92 & 0.60 & 3.40 & 4.31 & 0.53 & 3.93 & 10.94 & 1.47 & 11.45 \\
\hline T5 & 3.68 & 0.58 & 5.75 & 3.84 & 0.51 & 3.28 & 4.09 & 0.44 & 3.84 & 9.08 & 1.25 & 10.45 \\
\hline T6 & 3.55 & 0.51 & 5.64 & 3.39 & 0.47 & 3.13 & 3.94 & 0.34 & 3.39 & 7.95 & 1.06 & 8.96 \\
\hline T7 & 3.32 & 0.31 & 5.25 & 3.23 & 0.39 & 2.88 & 3.84 & 0.24 & 3.23 & 6.54 & 0.62 & 7.16 \\
\hline Mean & 4.18 & 0.54 & 5.86 & 3.78 & 0.55 & 3.30 & 4.24 & 0.47 & 3.78 & 10.28 & 1.35 & 10.87 \\
\hline CD (0.05) & 0.25 & 0.15 & 0.20 & 0.22 & 0.16 & 0.39 & 0.20 & 0.16 & 0.22 & 1.21 & 0.24 & 0.86 \\
\hline
\end{tabular}

Table.3 Evaluation of organic manures, fermented organics and PGPR on available macro and micronutrient content in soil under Capsicum (Capsicum annuum L.)

\begin{tabular}{|c|c|c|c|c|c|c|c|c|c|c|}
\hline \multirow[t]{2}{*}{ Treatments } & \multirow[t]{2}{*}{ pH } & \multirow[t]{2}{*}{ EC } & \multirow{2}{*}{$\begin{array}{c}\text { Organic } \\
\text { Carbon } \\
(\%)\end{array}$} & \multicolumn{3}{|c|}{ Macronutrient (kg ha $\left.{ }^{-1}\right)$} & \multicolumn{4}{|c|}{ Micronutrient (ppm) } \\
\hline & & & & $\mathbf{N}$ & $\mathbf{P}$ & $\mathbf{K}$ & $\mathbf{Z n}$ & $\mathbf{C u}$ & $\mathbf{F e}$ & Mn \\
\hline T1 & 6.63 & 0.70 & 1.23 & 428.03 & 71.70 & 279.30 & 1.37 & 1.82 & 5.66 & 1.76 \\
\hline T2 & 6.96 & 0.70 & 1.33 & 445.33 & 77.80 & 296.69 & 2.37 & 2.33 & 6.73 & 2.62 \\
\hline T3 & 7.53 & 0.64 & 1.30 & 440.43 & 74.16 & 284.42 & 1.72 & 1.98 & 5.88 & 2.05 \\
\hline T4 & 7.00 & 0.57 & 1.24 & 428.27 & 71.17 & 278.25 & 1.37 & 1.82 & 5.66 & 1.75 \\
\hline T5 & 7.10 & 0.73 & 1.19 & 403.61 & 67.56 & 273.52 & 1.28 & 1.31 & 5.16 & 1.61 \\
\hline T6 & 7.13 & 0.59 & 1.14 & 388.12 & 57.44 & 271.58 & 1.25 & 1.29 & 4.83 & 1.18 \\
\hline T7 & 6.96 & 0.78 & 1.03 & 374.77 & 67.29 & 264.70 & 1.19 & 1.24 & 4.76 & 1.08 \\
\hline Mean & 7.05 & 0.67 & 1.21 & 415.51 & 69.59 & 278.35 & 1.51 & 1.68 & 5.53 & 1.72 \\
\hline$C D_{(0.05)}$ & NS & NS & 0.04 & 5.49 & 3.48 & 7.94 & 0.70 & 0.73 & 1.09 & 0.54 \\
\hline
\end{tabular}


Table.4 Evaluation of organic manures, fermented organics and PGPR on various soil microbial properties in soil under Capsicum (Capsicum annuиm L.)

\begin{tabular}{|c|c|c|c|c|c|}
\hline Treatment & $\begin{array}{c}\text { Microbial } \\
\text { Count } \\
\left(\times 10^{5} \text { cfu g }^{-1}\right. \\
\text { soil })\end{array}$ & $\begin{array}{c}\text { Microbial } \\
\text { Biomass } \\
\left(\mu \mathrm{g} \mathrm{g}^{-1} \text { soil }\right)\end{array}$ & $\begin{array}{l}\text { Dehydrogenase } \\
\left(\mathrm{mg} \mathrm{TPF} \mathrm{h}^{-1} \mathrm{~g}^{-1}\right. \\
\text { soil) }\end{array}$ & $\begin{array}{l}\text { Urease } \\
\left(\begin{array}{l}\mathrm{mg} \mathrm{NH}^{4+} \\
\text { soil })\end{array}\right.\end{array}$ & $\begin{array}{c}\text { Phosphatase } \\
\text { ( } \mu \text { mole PNP } \\
h^{-1} g^{-1} \text { soil) }\end{array}$ \\
\hline $\mathbf{T 1}$ & 129.33 & 48.63 & 4.31 & 0.23 & 25.63 \\
\hline $\mathbf{T} 2$ & 147.33 & 60.33 & 4.96 & 0.28 & 30.41 \\
\hline T3 & 137.00 & 55.50 & 4.65 & 0.26 & 28.24 \\
\hline T4 & 130.00 & 49.53 & 4.30 & 0.23 & 25.60 \\
\hline T5 & 120.33 & 39.90 & 3.97 & 0.20 & 23.86 \\
\hline T6 & 109.00 & 25.73 & 3.40 & 0.16 & 22.94 \\
\hline T7 & 116.33 & 31.70 & 2.89 & 0.19 & 19.21 \\
\hline Mean & 127.05 & 44.48 & 4.07 & 0.22 & 25.13 \\
\hline $\mathrm{CD}_{(0.05)}$ & 6.98 & 10.58 & 1.02 & 0.05 & 1.35 \\
\hline
\end{tabular}

\section{Soil microbiological properties}

\section{Microbial count}

The viable microbial count differed significantly with application of Bulky and concentrated organic manures, liquid organic inputs and bio-fertilizers. The treatment $\mathrm{T}_{2}$ recorded maximum microbial count $\left(147.33 \times 10^{5} \mathrm{cfu} \mathrm{g}^{-1}\right.$ soil) whereas the lowest microbial count $\left(109 \times 10^{5} \mathrm{cfu} \mathrm{g}^{-1}\right.$ soil $)$ was recorded in treatment $T_{6}$. These findings are similar with results obtained by Jain et al., (2014), they reported that the application of Panchagavya, vermicompost and FYM increase microbial counts as compared to control.

Along with this maximum value of microbial biomass-C $\left(60.33 \mu \mathrm{g} \mathrm{g}^{-1}\right.$ soil) was recorded in $\mathrm{T}_{2}$. These results are in line with findings presented by Beckman, (1973); Udoh et al., (2005). The activity of various soil enzymes (Dehydrogenase, Phosphatase and Urease) also influence significantly by the application of different treatments. The maximum (4.96 mg TPF $\mathrm{h}^{-1} \mathrm{~g}^{-1}$ soil) value of dehydrogenase, was observed in treatment $T_{2}$ followed by Treatment $\mathrm{T}_{3}$ (4.65 mg TPF h $\mathrm{m}^{-1} \mathrm{~g}^{-1}$ soil), the treatment $\mathrm{T}_{1}$ (4.31 mg TPF h $\mathrm{m}^{-1} \mathrm{~g}^{-1}$ soil) was statistically at par with treatment $\mathrm{T}_{4}(4.30 \mathrm{mg}$ TPF $\mathrm{h}^{-1} \mathrm{~g}^{-1}$ soil) as given in Table 4.

These findings are similar with those of Kohler et al., (2007) who also reported that by application of PGPR, alone or in consortium, there is increase in dehydrogenase in rhizospheric soil in lettuce. The application of organic amendments also influences phosphatase activity. Significantly higher (30.41 $\mu$ mole $\mathrm{PNP} \mathrm{h}^{-1} \mathrm{~g}^{-1}$ soil) value of phosphatase was observed in treatment $T_{2}$. Treatment $\mathrm{T}_{1}\left(25.63 \mu\right.$ mole PNP h${ }^{-1} \mathrm{~g}^{-1}$ soil $)$ was statistically at par with treatment $\mathrm{T}_{4}$ (25.60 $\mu$ mole PNP $\mathrm{h}^{-1} \mathrm{~g}^{-1}$ soil) and lowest (19.21 $\mu$ mole PNP $\mathrm{h}^{-1} \mathrm{~g}^{-1}$ soil) value of phosphatase enzyme was noted in treatment $\mathrm{T}_{7}$. 
These results are in line with findings of Kohler et al., (2007) which stated that due to the application of PGPR, there is increase in phosphatase activity near the rhizospheric soil. The urease enzyme activity also influenced by different treatments enumerated in Table 4. It was found that significant higher (0.28 mg $\mathrm{NH}^{4+} \mathrm{g}^{-1}$ soil) value of urease enzyme activity was recorded in treatment $\mathrm{T}_{2}$.

However lowest $\left(0.16 \mathrm{mg} \mathrm{NH}^{4+} \mathrm{g}^{-1}\right.$ soil $)$ value of urease enzyme activity was reported in treatment $\mathrm{T}_{6}$. These results are similar with findings of Albiach et al., (2000) and Nayak et al., (2007), they stated that soil enzymes activities are influenced by the application of organic inputs and compost in the soil.

\section{References}

Albiach, R., Cancet, R., Pomares, F., Ingelmo, F. 2000. Microbial biomass content and enzymatic activities after the application of organic amendments to a horticultural soil. Bioresource Technology 75: 43-48.

Aniekwe, L., and Nwokwu, G. 2013. Effects of organic manure sources on the growth and yield of watermelon in Abakaliki, South Eastern Nigeria. International Journal of Science and Research 4(1): 2319-7064.

Anonymous. 2016. Indian Horticulture Database. National Horticulture Board, Gurgaon.

Aziz, T., Ullah, S., Sattar, A., and Khan, M.M. 2010. Nutrient availability and maize (Zea mays) growth in soil amended with organic manures. International Journal of Agriculture and Biology 12: 621-624.

Beckman, E.O. 1973. Organic fertilization: vegetable farming luxury or necessity. Tech. Commun. ISHA 29: 247p.

Boateng, S., Zickermann, A.J., and Kornaharens, M. 2006. Effect of poultry manure on growth and yield of maize. West African Journal of Applied Ecology 9: 1-11.

Brar, P.S., Kaushal, R., and Bhardwaj G. 2019. A Review on Beneficial Effects of PGPR and Noble Liquid Manures in Enhancing Soil Fertility and Sustainability. Int.J.Curr.Microbiol.App.Sci. 8(04): 409-
415.

Brar, P.S., Kaushal, R., Bhardwaj, G., and Sharma, U. 2020. Effect of manures, soil recipes and PGPR on soil and plant quality parameters in bell pepper. International Journal of Chemical Studies 2020; 8(1): 2228-2231

Brar, P.S., Kaushal, R., Bhardwaj, G., and Sharma, U. 2020. Yield and fruit quality response of PGPR, bulky and folk liquid manures on capsicum (Capsicum annuum L.) in Western Himalayas of India. Journal of Pharmacognosy and Phytochemistry 2020; 9(1): 1385-1390.

Casida, L.E., Klein, D.A., and Santoro, T. 1964. Soil dehydrogenase activity. Soil Science 98: 371-376.

Follett, R.H., Murphy, L.S., and Donahue, R.L. 1981. Fertilizers and soil amendments. Prentice-Hall Inc., Englewood Cliffs, New Jersey, USA.

Hoffman, E. 1965. Methods of enzymatic analysis H. Bergmeyer (ed.) Academic Press. New York pp. 219-221.

Jackson, M.L. 1973. Soil chemical analysis. Prentice Hall of India Pvt. Ltd., New Delhi. pp. 111-126.

Jain, P., Sharma, R.C., Bhattacharyy, P. 2014. Effect of new organic supplement (Panchgavya) on seed germination and soil quality. Environmental Monitoring and Assessment 186(4): 1999-2011.

Kohler, J., Caravaca, F., Carrasco, L., and Roldan, A. 2007. Interactions between a plant growth-promoting rhizobacterium, an AM fungus and a phosphate-solubilising fungus in the rhizosphere of Lactuca sativa. Applied Soil Ecology 35: 480-487.

Legaspi, J.C., Gilbert, C.G., Leppla, Q.N., Cuda, J., and Legaspi, B.C. 2007. Effect of organic and chemical fertilizers on growth and yield of hot pepper, and insect pests and their natural enemies. Subtropical Plant Science 59: 75-84.

Lindsay, W.H., and Norvell, W.A. 1978. Development of DTPA soil test for $\mathrm{Zn}, \mathrm{Fe}$, $\mathrm{Mn}$ and $\mathrm{Cu}$. Soil Science Society of American Journal 42: 420-428.

Mehdi, S.M., Sarfaraz, S.M., Abbas, S.T., Shabbir, G., and Akhtar, J. 2011. Integrated nutrient management on rice and wheat 
cropping system in a recently claimed soils. Journal of Soil Science and Environment Management 30(1): 36-43.

Merwin, H.D., and Peech, M. 1951. Exchange ability of soil potassium in the sand, silt and clay fractions as influenced by the nature and complementary exchangeable cations. Soil Science American Proceedings 15: 125-128.

Mia, M.A.B., Shamsuddin, Z.H., Wahab, Z., and Marziah, M. 2010. Effect of plant growth promoting rhizobacterial (PGPR) inoculation on growth and nitrogen incorporation of tissue-cultured Musa plantlets under nitrogen-free hydroponics condition. Australian Journal of Crop Science 4(2): 85-90.

Nayak, D.R., Babu, Y.J., and Adhya, T.K. 2007. Long-term application of compost influences microbial biomass and enzyme activities in a tropical Aeric Endoaquept planted to rice under flooded condition. Soil Biology and Biochemistry 39: 1897-1906.

Nwachukwu, C.U., Mbagwu, F.N., and Onyej, A.N. 2007. Morphological and leaf epidermal features of Capsicum annuum and Capsicum frutescens solanaceae. Nature and Science, 5: 54-60.

Olsen, S.R., Cole, C.U., Wattannabe, F., and Sandean, D.A. 1954. Estimation of available phosphorus in soil by extraction with sodium bicarbonate. USDA circulation. 939p.

Ravimycin, T. 2016. Effects of Vermicompost (VC) and Farmyard Manure (FYM) on the germination percentage growth biochemical and nutrient content of Coriander (Coriandrum sativum L.). International Journal of Advanced Research in
Biological Sciences 3(6): 91-98.

SubbaRao, N.S. 1999. Soil microorganism and plant growth. Oxford \& IBH publishing Company, New Delhi. 252p.

Subbiah, B.V., and Asija, G.L. 1956. Rapid procedure for the estimation of the available nitrogen in soils. Current Science 25: 259-260.

Tabatabai and Bremner. 1969. Use of pnitrophenyl phosphate for assay of soil phosphatase activity. Soil Biology and Biochemistry 1: 301-317.

Turan, M., Medine, A., Gulluce, B., Cakmakci, R., Oztas, C.T., and Sahin, S.F. 2010. The effect of PGPR strain on wheat yield and quality parameters. $19^{\text {th }}$ World Congress of Soil Science, Soil Solutions for a Changing World, 1-6 August 2010, Brisbane, Australia.

Udoh, D.J., Ndon, B.A., Asuquo, P.E., and Ndaeyo, N.U. 2005. Crop production techniques for the Tropics. Concept Publication, Lagos, Nigeria. 446p.

Vance, E.D., Brookes, P.C., and Jenkinson, D.S. 1987. An extraction method for measuring soil microbial biomass C. Soil Biology and Biochemistry 19: 703-707.

Walkley, A., and Black, T.A. 1934. An experimentation of vegetative method for determining soil organic matter and proposed modification of the chromic acid titration method. Soil Science 37: 38-39.

Weber, J., Karczewska, A., Drozd, J., Licznar, M., Licznar, S., Jamroz, E and Kocowicz, A. 2007. Agricultural and ecological aspects of a sandy soil as affected by the application of municipal solid waste composts. Soil Biology and Biochemistry 39: 1294-1302.

\section{How to cite this article:}

Perminder Singh Brar, Rajesh Kaushal, Gitika Bhardwaj. 2020. Evaluation of Organic Manures, Fermented Organics and PGPR on Plant Growth and Soil Properties under Capsicum (Capsicum annuum L.). Int.J.Curr.Microbiol.App.Sci. 9(06): 1413-1421. doi: https://doi.org/10.20546/ijcmas.2020.906.176 